The community is supporting our schools that we may turn out better citizens of a democracy. We are emphasizing physical health, vocational efficiency, worthy use of leisure, ethical character, and other elements that were formerly omitted or only vaguely implied as objectives of education. But health of the spirit and loyalty to the principles of our social order are essential to our personal happiness and our national safety. We have learned that instruction to be effective must pass over into habit, and that the emotions as well as the intellect must be trained. The textbook, therefore, is more and more becoming a laboratory manual; the incorrigible "lecturer" in high school is being asked to go and sell life insurance. In short, we are learning by doing. The burden of my contention is that we apply these principles in our administration, and answer the question, "Why have high schools?" by making our schools laboratories of democracy.

Mr. Clarence D. Kingsley, State High School Supervisor of MAssachusetTs, made a "Presentation of Certain Features in the Report on Cardinal Principles of Secondary Education."

\title{
CERTAIN FEATURES IN THE REPORT ON CARD- INAL PRINCIPLES OF SECONDARY EDUCATION
}

CLARENCE D. KINGSLEY, STATE HIGH SCHOOL SUPERVISOR, MASSACHUSETTS

Is there need today for a concise statement of the underlying principles which should guide the reorganization and development of secondary education? It is the hope of the Commission on the Reorganization of Secondary Education that it has succeeded in making such a statement in its report entitled "Cardinal Principles of Secondary Education"1 and it is the further hope of the Commission that this report may so commend itself to administrators and teachers as to receive serious study and consideration. While the report occupies only thirty pages it deals with many problems. I shall confine my remarks to four of them, namely, admission to high school, the objectives of education, the supplementary character of specialization and unification, and part-time education.

${ }^{1}$ See Bulletin, 1918, No. 35, of Bureau of Education. On sale by Superintendent of Documents, Washington, D. C. 5c a copy. In lots of 50 or more, $3 \mathrm{c}$ a copy. 
The junior high school is now so well established in educational theory that it will occasion no surprise when I say that the Commission in 1913 decided to regard secondary education as beginning with the seventh school year. In order, however, that all pupils who need what the secondary school has to offer may share in its advantages, the Commission recommends "that the secondary school admit and provide suitable instruction for all pupils who are in any respect so mature that they would derive greater benefit from the secondary school than from the elementary school." This recommendation is based upon the fact that many pupils now held back in the fifth and sixth grades by rigid academic requirements need the contact with pupils of their own age and the varied provisions which the junior high school can make for them. The adoption of this recommendation would benefit both the elementary school and many over-age pupils thus promoted.

To the problem of selecting and defining the objectives of education the Commission has devoted much attention. The all-inclusive function of education is that of preparing the individual for worthy living in democratic society. In a broad sense this may be summed up by the term "Citizenship" but the single term is not sufficient to guide and direct the efforts of the schools. Consequently the Commission sets forth the following seven as the main objectives of education:

\author{
Health \\ Worthy Home-Membership \\ Vocation \\ Citizenship \\ Worthy Use of Leisure \\ Ethical Character
}

Command of Fundamental Processes

All these seven objectives are indispensable to "citizenship" in the broadest term. They are useful for three purpose.

First: In determining the aims, methods, and content of the various subjects of study.

Second: As a basis for criticizing the various differentiated curriculums, and

Third: As indicating certain functions for which specific provision should be made in the administration of the school.

The Reviewing Committee has already found that these objectives are a direct help in criticizing reports on the various subjects of study. We believe that teachers will, to the extent to which they reorganize 
their educational thinking, find that these objectives assist in directing their instruction toward ends of far greater value in the education of young people. Any curriculum in which any of these objectives is ignored or given slight attention needs to be seriously reconsidered in order that the education of boys and girls pursuing that curriculum may not be seriously defective. With regard to the organization of the school these objectives suggest the desirability of forming a principal's council, each member of which shall be specifically charged with the duty of making the school more effective in the achievement of a particular objective. Such a council in a large school might include a health director, a citizenship director, a director of vocational and educational guidance, directors of the various curriculums including a director of college preparation, and a director of social or leisure activities. In some schools it may be found more feasible to appoint committees for each of these purposes.

The suggestion for a principal's council is based upon the idea that the majority of administrators tend to become absorbed in certain aspects, as it is practically impossible to keep all phases of the school's work in view at one time. It is of course not intended that the council or the committees should in any way lessen the ultimate responsibility of the principal but that with the aid of a council or committees the principal may be able to develop all ${ }^{*}$ aspects of secondary education.

The third problem to which I would call your attention is that of the supplementary character of the specializing and unifying functions of secondary education. Without specialization in a democracy there can be no progress. On the other hand the permanence of democratic society depends upon the development of those common ideas, common ideals, and common modes of thought, feeling and action that make for co-operation, social cohesion, and social solidarity. Consequently the secondary school must consciously aim to be effective both as an agency of specialization and as an agency of unification. The supplementary character of these functions leads the Commission to state that the greater the differentiation in studies the more important becomes the social mingling of pupils pursuing the different curriculums. This leads at once to a consideration of the type of secondary school best adapted to the needs of democratic society. The Commission takes the position that the junior high school must be of the comprehensive type from the very nature of its function in helping pupils to explore their aptitudes in various 
lines and that the comprehensive high school should remain the standard type for senior high schools.

The strongest argument ordinarily presented for the comprehensive school as distinguished from specialized schools is that the comprehensive school tends to prevent social stratification. This report, however, goes further and points out the advantages to both pupils and teachers that come through association with persons engaged in lines of activity other than their own. It also shows that the comprehensive school can be more effective in vocational education in view of the fact that one of the factors of efficiency of any particular type of education is the degree to which it is given to those persons who need that particular type of education. Wise selection of curriculum and readjustments in choice, when such readjustments are found desirable, are rendered much easier in the comprehensive school than in the specialized school. Furthermore the Commission points out that the large comprehensive school is able to provide much more effectively for health education, education for the worthy use of leisure and home-making education than can a number of smaller special type schools. In recommending the comprehensive school the Commission warns against the inefficiency that may arise if the head of such a school is a man of narrow outlook or limited interests or if the faculty is not so organized as to develop each curriculum to the utmost efficiency consistent with the civic and social needs.

The fourth problem, that of part-time, or continuation, education is probably the most important problem in the field of secondary education today. The establishment of part-time education is rendered imperative in view of the fact that young people in large numbers leave school before they have secured the amount of education essential under modern conditions and while they are still in the formative and highly plastic secondary school period. In the United States as a whole not more than one-sixth to one-ninth of the rising generation are graduated from the secondary school, while probably not more than one-third enter the first year of the four-year high school, or the third year of the junior high school. Certainly four or five times as many persons between the ages of fourteen and eighteen are out of school as there are in the secondary school. Consequently the quality of four-fifths to five-sixths of the future citizenship will be profoundly affected by the solution which is made of this problem of part-time education. England and 
France have already taken steps looking toward the universal requirement of such part-time education and the social forces in the United States are becoming aroused to the importance of similar action.

In anticipation of such legislation it is of the utmost importance that school administrators should be ready with answers to the questions "What kind of education do such youth need and where should it be offered?"

In determining the type of part-time education, the objectives already sketched are helpful. It is evident that young workers have important health needs. They are likely to develop physical defects growing out of the nature of their occupational work and they all need health instruction and guidance in the formation of correct health habi ts. They need stimulation and guidance in the worthy use of leisure. Many of them have left school before they have had opportunity to develop those avocational interests which would be most beneficial for them. Their increased maturity since leaving school and their new social contacts make possible effective civic education such as they could not have obtained earlier. The vocational education for some of these persons may well be designed to enable them to advance more rapidly in the work upon which they have entered. For others, however, it should not be related to their regular employment but should be designed to help them to a vocation better adapted to their abilities and having more opportunities for advancement, for it must be remembered that many young workers enter into blind-alley occupations. In view of these considerations part-time education should be broad in scope and should be adapted to the needs of individuals or groups of individuals.

As to the place where continuation education should be offered the Commission urges that it should be conducted in comprehensive secondary schools rather than in separate continuation schools, as is the custom in less democratic societies. "By this plan the parttime students and the full-time students may share in the use of the assembly hall, gymnasium, and other equipment provided for all. This plan has the added advantage that the enrollment for all pupils may be continuous in the secondary school, thus furthering employment supervision on the one hand and making easier a return to full-time attendance whenever the lure of industry relaxes or the improvement of economic conditions in the family makes such a return inviting and feasible." 
In concluding this presentation may I quote the three last paragraphs of the report:

"It is the firm belief of this Commission that secondary education in the United States must aim at nothing less than complete and worthy living for all youth, and that therefore the objectives described herein must find place in the education of every boy and girl.

"Finally, in the process of translating into daily practice the cardinal principles herein set forth, the secondary school teachers of the United States must themselves strive to explore the inner meaning of the great democratic movement now struggling for supremacy. The doctrine that each individual has a right to the opportunity to develop the best that is in him is reënforced by the belief in the potential, and perchance unique, worth of the individual. The task of education, as of life, is therefore to call forth that potential worth.

"While seeking to evoke the distinctive excellencies of individuals and groups of individuals, the secondary school must be equally zealous to develop those common ideas, common ideals, and common modes of thought, feeling, and action, whereby America, through a rich, unified, common life, may render her truest service to a world seeking for democracy among men and among nations."

Principal James N. Rule, of Schenley High School, Pittsburgh, Pennsylvania, addressed the Association on

\section{THE PLACE OF THE MODERN SECONDARY SCHOOL IN A DEMOCRACY}

JAMES N. RULE, SCHENLEY HIGH SCHOOL, PITTSBURGH, PENNSYLVANIA

The permanence and the free and full development of democratic institutions and ideals depend primarily not upon the degree of military preparedness but upon the degree of preparedness of each individual member of the democracy to fill conscientiously and skilfully and joyously the particular place in the life of his community which nature has fitted him best to fill. In the light of this statement, the degree of preparedness of our American democracy to meet effectively and happily the issues of the world democracy now in process of formulation in the hearts and minds of the 